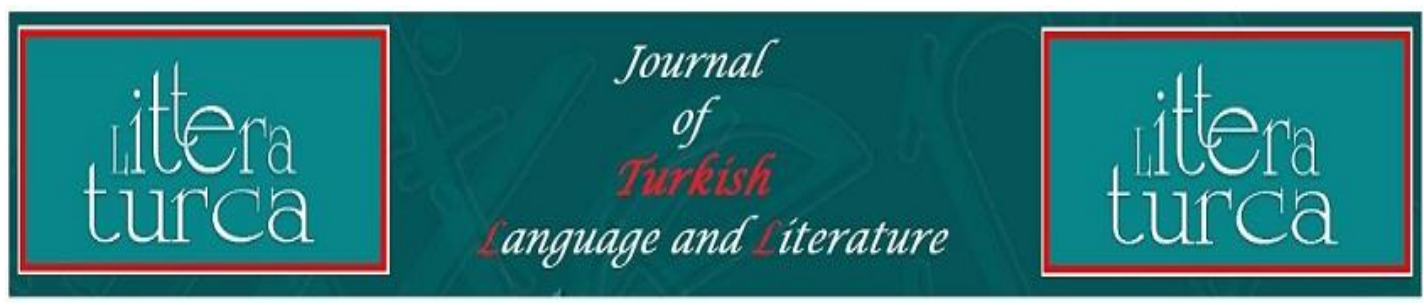

\title{
PEND-NÂME-i ASKERî
}

\section{Gönül DELiCE ${ }^{1}$}

\section{Özet}

Klasik Türk edebiyatında pendnameler önemli bir türdür. Pendnameler, insanlara öğüt verme gayesiyle yazılmış manzum ve mensur eserlerdir. Genel anlamda; insanlara doğruyu, yanlışı, iyiyi, kötüyü göstermek ve insanları doğru yola sevk etmek amacıyla yazılmıştır. Bunu yaparken de ayet ve hadislerden, atasözlerinden, halk hikâyelerinden, günlük yaşamdan yararlanılmıştır. Bunlardan birisi de 16. yüzyılda Kanunî devrinde yaşamış olan Askerînnin Pend-nâme-i Askerî adlı eseridir. Bu eserde Askerî, eşcinselleri konu almış ve onlara öğütlerde bulunmuştur.

Çalışmamızda öncelik olarak pend-nameler hakkında bilgiler verip Askerînnin hayatı, eserleri ve edebî kişiliğine değindik. Pend-nâme-i Askerînnin yazmalarını tavsif edip şekil ve muhteva özellikleri hakkında bilgi verdik. Daha sonra nüsha farklarını dipnotlarla belirttik.

Anahtar Kavramlar: Pendname, klasik Türk edebiyatı, yazma eser, bent, muhteva.

\section{PEND-NÂME-İ ASKERÎ}

\section{Abstract}

Pendnames very important literary genre in Classical Turkish Literature. They are poetical and prosaic Works written for giving advice to people. Generally they were written for showing rihgt, wrong, good and bad to people and putting them to the right way. While doing it, the verses of the Koran and hadiths, proverbs, folktales and daily life were used. They are also called nasihatname. Lived in $16^{\text {th }}$ century during the era of Suleiman the Magnificient, Askerî's Pend-nâme-i Askerî is one of these books.

In the introduction of our study, we primarily mentioned about Askerî's life, works and literary personality. We tired to give information about Pendnameler. We gave information about shape and content features on manuscripts of Pend-nâme-i Askerî. Later we pointed out copy differences with footnotes.

Keywords: Pendname, The Classical Turkish Literature, manuscript, the content.

\footnotetext{
* "Pend-nâme-i Askerî” adlı Yüksek Lisans Seminerinden üretilmiştir.

${ }^{1}$ Giresun Üniversitesi, Sosyal Bilimler Enstitüsü, Turk Dili ve Edebiyatı Ana Bilim Dalı Yüksek Lisans Öğrencisi, gonul_dlce@hotmail.com.
}




GíRiş

Türk edebiyatında pendname ${ }^{2}$ türünde yazılmış eserlerin sayısı oldukça fazladır. Pendnameler, genel anlamda insanlara nasihat etmek, insanları doğru yola sevk etmek ve bilgilendirmek maksadıyla yazılmıştır. Farsça bir kelime olan “pend”in sözlük manası “öğüt”tür. Öğüt ise doğru yolu göstermek amacıyla bir kimsenin yapması ya da yapmaması gereken davranış ve eylemler hakkında söylenen sözlerdir. Pendnamelere "nasihatname" de denilmektedir. Arapça "nasaha” kökünden türeyip öğüt manasına gelmektedir. Farsça mektup, kitap, ferman anlamlarına gelen "name" ile birleşmesi sonucu ortaya çıkan nasihatname; insanları iyiye, doğruya, güzele yönlendirerek onları ahlâkî ve sosyal açıdan olgunluğa ulaştırmayı amaç edinen didaktik eserlerin genel adıdır.

Türk edebiyatında nasihat verir şekilde eserlerin yazımının ilk örneklerini Göktürk Kitabelerinde görmekteyiz. Göktürk Devleti hükümdarı Bilge Kağan, Türk boylarının birlik içinde yaşamaları, büyüğün ve küçüğün atalarını sayması, düşman devletlere karşı dikkatli olmanın gerekliliği gibi birçok hususta Türk milletine öğütler vermektedir. İslamiyet'in kabul edilmesinin ardından, İslamî Türk edebiyatının ilk örneklerinden sayılan Yusuf Has Hacip'in Kutadgu Bilig adlı eseri de toplum hayatındaki bozuklukları düzeltecek, insanları mutlu edecek yolların neler olduğu belirtilmiştir. Edip Ahmet Yükneki'nin Atabetü'l-Hakayık adlı eseri ise ahlaklı insan olmanın yollarını, ahlak ilkelerini açıklamış ve çeşitli ahlakî öğütlerde bulunmuştur. Anadolu sahasında kaleme alınan ilk Türkçe nasihatname olarak Ahmed Fakih'in Çarh-name ve Yunus Emre'nin Risaletü'n-Nushiyye adlı eserleri de pendname tarzında kaleme alınmıştır. Bunların yanında Hacı Bektaş-ı Veli, Âşık Paşa, Mevlana ve Ahmet Yesevî gibi birçok şairimiz pendname gibi didaktik şiirler kaleme almışlardır.

Nasihat verir tarzdaki eserlerin pendname olarak adlandırılması geleneği İslamiyet'in kabulünden sonraki döneme rastlar. Bu tür eserlerin yazımında Feridüddin-i Attar’ın Pend-name isimli eserin adından esinlenilmiştir. Bu eser, yüzyıllardan bu yana doğu kültürlerinde geniş ve derin bir ilgi ile okunmuş, tasavvufî görüş ile İslam ahlakını geniş kitlelere ulaştırıp yayma konusunda büyük rol oynamıştır. Daha sonra bu yolda verilen eserlere örneklik etmiştir (Kutlu 1990: 241-242). Bununla birlikte konusu ve kendisi yerli olan ve Attar'ın Pendname'sinden tamamıyla ayrı özellikleri bulunan pendnameler de yazılmıştır. İşte bunların içinde en önemlisi Güvâhi'nin Pend-nâme'sidir. Attar'ın Pend-name'sinde ahlakî konular tasavvuf açısından işlenmiştir. Güvâhî ise daha çok çevresinde gördüğü, duyduğu ve kendi başından geçen olayları gerçekçi bir açıdan ele almış, bunları kısa hikâye, latife ve fıkralar biçiminde anlatarak, sonunda atasözleriyle öğütler vermiştir. Oysa Attar'ın Pendname'sinde bunlara benzer hikâye, fıkra biçiminde anlatımlar yoktur. Öğütler doğrudan doğruya konuyu ilgilendiren başlıklar altında verilmiştir (Hengirmen 1983: 16-17).

Mahmut Kaplan nasihat-nameleri konularına, nazım şekillerine, te'lif veya tercüme oluşlarına göre aşağıdaki şekilde sınıflandırmıştır:

\footnotetext{
2 Pendname ve nasihatname kavramı ile ilgili bilgiler, (Ekinci 2012: 423-441) ve (Güven 2009: 182-197)’den yararlanılarak verilmiştir.
}

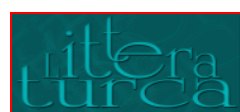


1) Konularına Göre Nasihat-nameler:

a. Dini-tasavvufi nasihat-nameler

b. Sosyal muhtevalı nasihat-nameler

c. Çeşitli ilimlerle ilgili nasihat-nameler

2) Nazım Şekillerine Göre Nasihat-nameler

a. Mesnevi şekliyle yazılan nasihat-nameler

b. Kaside şekliyle yazılan nasihat-nameler

c. Gazel şekliyle yazılan nasihat-nameler

d. Terci-i bend şekliyle yazılan nasihat-nameler

3) Te'lif veya Tercüme Oluşlarına Göre Nasihat-nameler (Kaplan 2008: 2-3).

Pendnameler, manzum ve mensur olarak gazel, mesnevi, terci-i bent ve kaside nazım şekilleriyle kaleme alınmış eserlerdir. İnsanları iyiye, güzele ve doğruya yöneltmek, topluma yararlı, iyi ahlaklı bireyler yetiştirmek amacıyla yazılmışlardır. Pendname yazmanın amacı aslında İslamiyet'in “iyiliği emretme, kötülükten sakındırma” ilkesine uymaktır. Bu noktadan hareketle pendnamelerin kaynağını ayetler ve hadisler oluşturur diyebiliriz. Ayrıca pendname hakkındaki kaynakları incelediğimiz zaman pendnamelerin kaynağını sadece ayet ve hadislerin oluşturmadığını; günlük hayatın, tarihî olay ve hikâyelerin en önemlisi de atasözlerinin pendnamelere kaynaklık ettiğini görmekteyiz.

Üzerinde durulması gereken pendnamelerden birisi de Pend-nâme-i Askerî̀dir. Askerî’nin asıl adı Mehmed olup Edirne'de doğmuştur. Doğum tarihi bilinmemektedir. Bağdat'ta İmam Hasan Askerî̀nin maiyetine girmiş ve uzun bir süre onun dergâhında kaldığı için şiirlerinde Askerî mahlasını kullanmıştır. Kanunî Sultan Süleyman devri şairlerindendir ve onun bazı şiirlerini tahmis etmiştir. Yeniçeri ve tımar sahibi olmuştur. Kaynaklarda Edirne veya Vardar Yenice'sinden olduğu da söylenmektedir (Kaplan 2008: 17). Uzun süre Kerbela'da İmam Hüseyin'in türbesinde bulunmuş ve Seyyid Gazi dergâhına Horasan sultanının selamını getirmiş derviş tabiatlı biridir. Daha sonra zeamet alarak Selanik'e yerleşmiş ve orada İshak Paşa'nın oğlunun hanımı ile evlenmiş, büyük bir servete sahip olmuştur. Askerî hacca gitmiş; fakat Râfizî olduğu öne sürülmüş ve bir türlü dinsizlik ithamlarından kurtulamamıştır. Ölümü 1000/1591-92 tarihidir (Kaplan: 2014).

Kaynaklar, Askerî’ye ait herhangi bir eserin varlığından bahsetmez. Ancak çeşitli şiir mecmualarında terci-i bent, muhammes, müseddes gibi nazım şekilleriyle kaleme almış olduğu birçok şiire rastlanmaktadır. Derviş tabiatlı bir kişi olduğu için şiirleri de rindane ve tasavvufî özellikler taşımaktadır. Ayrıca Âşsk Çelebi, Askerî’nin şiirlerini

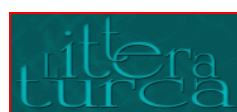


sade bulurken (Kılıç 2010: 1080) Hasan Çelebi ise bunları beğenmemiştir (Kutluk 1989: 632). Askerî’nin söz konusu şiirlerinden biri de Pend-nâme-i Askerî adlı manzumedir.

Pend-nâme-i Askerînnin yazmalarının tavsifi şu şekildedir:

1.Mecmû'a-i Eş'âr (M), Milî̃ Kütüphane Yazmalar Koleksiyonu, 06 Mil Yz A 799/de kayıtlıdır. 100 yaprak olup satır sayısı değişiktir. Pend-nâme-i Askerî yazmanın 84b-89b yaprakları arasındadır. Mecmuanın istinsah tarihi ve derleyeni / müstensihi belli değildir.

2.Mecmû'a (T), Topkapı Sarayı Müzesi Türkçe Yazmaları Koleksiyonu R. 1207'de kayıtlıdır. 134 yaprak olup satır sayısı değişiktir. Pend-nâme-i Askerî yazmanın 3b-8a yaprakları arasındadır. Mecmuanın istinsah tarihi ve derleyeni / müstensihi belli değildir.

\section{Pend-nâme'nin Biçim ve İçeriği}

Ayrıca terci-i bent şeklinde ve aruzun "fe'ilâtün mefâ'ilün fe'ilün" vezniyle yazılmış olan Pend-nâme-i Askerî 14 bentten ibarettir. VII, VIII, X, XI ve XII. bentler on, diğerleri ise on bir beyitten oluşur. Toplamda ise 149 beyittir.

Pend-nâme-i Askerînnin konusu, genel anlamda oğlanlardan³ uzak durma hakkında verilen öğütler etrafında şekillenmiştir. Her toplumda olduğu gibi Osmanlı döneminde de eşcinsel eğilimler olmuş ve bu eğilimler edebiyata belli şekillerde yansımıştır. Bu bağlamda Askerî́nin pendnamesi de eşcinsel eğilimler üzerinedir.

I. bentte şair söze; güzel yüzlülerle birlikte olunmamasından, onlara fazla meyledilmemesinden bahsederek başlar. Oğlanların sohbetinden, onlarla birlikte olma düşüncesinden uzak durulmalıdır. Onların sevgi sözlerine aldanılmamalıdır. İnsan, nefsine uyup kendine kötülük etmemelidir. Oğlanların ömrü kahpelik ve oğlanlık etmek ile geçmektedir. Terbiyeden anlamazlar, insanın başına ne gelirse onlardan gelir. Dolayısıyla onlara güvenilmemelidir.

II. bentte baştan ayağa gümüş paraya boğulsalar da oğlanların asla yâr olamayacağı, yüze gülüp başkalarına yöneleceği, hilede usta oldukları, şeytanın bile hileyi onlardan öğrendiği, yüzlerini görmemenin mutluluk kaynağı olduğu anlatılmaktadır.

III. bentte oğlanlara meyledenlerin köpekten aşağı olacağı, gönül verenlerin büyük bir yük altına gireceği, oğlanların inatçı olup insanları bıktırdıkları, kendini gerçekten sevenlere ayda bir kere yüz gösterdikleri, kendilerine yapılan iyiliği inkâr ettikleri yani nankör oldukları, namussuzlukları ile arsızlıkları dile getirildikten sonra şair, onlara düşkün olmamak için Allah'a yalvarmaktadır.

IV. bentte şair, oğlanların kendilerini seçkin gördüklerini, yüz buldukça eziyeti çok vefayı az gösterdiklerini dile getirir. İnsanı ağlatıp kendilerinin de başkalarıyla dostluk kurduğunu ve ar ile namusu terk ettiklerini, elden

\footnotetext{
3 “Oğlan”, Güncel Türkçe Sözlük’te “Cinsel bakımdan erkeklerin zevkine hizmet eden sapık erkek” olarak tanımlanmaktadır.
}

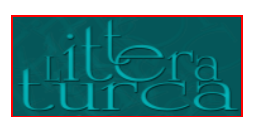


utanmadıklarını söyler. "Leşe kargalar talip olur, hiç doğan leşe talip olur mu?" diyerek oğlanların ne kadar kötü olduklarını dile getirir.

V. bent, oğlanların oldukça ahlâksız oldukları ve âşıkların bunlara meyletmemesi dileğiyle başlar. Her bir alçak, masumiyet perdesini ayaklar altına almıştır. Bir bölük ateşperestlerle gece gündüz sefa sürerler. Onlarla birlikte olmak insanlara mutsuzluk getirir. Bunların meyli nefsine düşkün olanlardır. Hiçbirinde vefa yoktur, her önüne gelene karşılık verirler. Dünyanın başlangıcından beri âşığa acımazlar. İnsanda zerre kadar idrak varsa bunlardan uzak durmalıdır.

VI. bentte söze, âşıkların herkese gönül verenlerden incindiği söylenerek başlanmıştır. İnsan, oğlanlardan korkmalı ve uzak durmalıdır, onlara gönül vermemelidir. Bunlar gerçek âşığa meyletmezler; yanlarında ikiyüzlü dostları vardır. Birini gördüklerinde hemen âşığını terk ederler, diğerine yönelirler. Gerçek âşığına hep eziyet ederler. Kendilerini namuslu gösterip tenhalarda arsızca davranırlar. Âşıkları birbirine düşürürler. Bunlardan uzak duranlar, yoksulluğa ve felâkete uğramazlar. İnsan, bunlarla yiyip içip Allah’a asi olmamalıdır.

VII. bent, delikanlıların melek gibi masum oluşlarına aldanıp onlar için çaba sarf etmeme öğüdü ile başlar. Oğlanların gece gündüz yaptıkları, âşıkları aldatmaktır. Hiçbirisi yapılan iyiliği görmez, hepsi nankördür. Onların yolunda can verilse de umursamazlar. Güzelliğe düşkündürler. İnsanlara vefasızlığı bunlar öğretirler. Daha iyisini görürlerse hemen diğerini terk ederler. Bunlardan uzak durmak gerekir.

VIII. bentte oğlanların hilekâr ve düzenbaz oldukları anlatılmaktadır. Kendisine bağlananları aldatırlar, utanmazdırlar, bilgiden uzak ve mal mülk düşkünü kimsedirler, iyilikten anlamazlar, âşıklarını bırakıp başkaları ile gönül eğlendirirler, meyilleri hep başkasınadır, her ne kadar yalın yüzlü olsalar da hepsi kötü işlerle uğraşmaktadır.

IX. bentte Askerî, oğlanların aklının, gece gündüz içki meclislerinde olduğu üzerinde durur. Ona göre oğlanların gözü paradadır, para yoksa âşığına ilgi göstermezler ve arkasından gıybet ederler; yeryüzündeki bütün taşlar, altın ve gümüş olsa da kahpe ve oğlana yetmez.

X. bentte yine oğlanların benzer özellikleri üzerinde durulur. Gönlünü kıranların sözüne kötülükle karşılık verirler. Bazen gülerek bazen söverek nazlanırlar ve eziyet ederler. Âşığının yerine her soysuza meylederler. Şarap kadehiyle gece gündüz, köşe bucak dolaşırlar. Yaptıkları ayıp hesaba gelmez. Gösterişe meyillidirler ve namuslusu pek nadirdir.

XI. bentte Askerî, oğlanlardan uzak durma ve her güzele kapılmama konusu üzerinde durur. Oğlanlar, her gün müşterinin çok olmasını ister, kendisini süsleyip satar. Birlikte oldukları kimselerin başına bela getirirler. Âşık, ne kadar canını onun yoluna koysa da o vefa göstermez. Âşığının parasını yiyip başkasına yüz gösterir.




XII. bentte de oğlanlardan uzak durma konusu işlenmiştir: Oğlanlar, başkalarına güler yüz gösterirken âşığını kahrederler. Kendilerini on iki yaşında bir genç olarak görürler. Bunlar zina yapmaya alışmışlardır. Utanmadan, gece gündüz zina ederler. Bunlar, şeytan ile dindaştırlar. Bunların ahlâksızlığını anlatmaya kelimeler yetmez.

XIII. bentte güzellerin çeşitli özellikleri üzerinde durulur: Güzeller insafsızdırlar, âşı̆̆a cefa ederler. Temiz kalbi olanlar, oğlanlara meyletmez. Çünkü onların her biri, bir alçakla etrafı seyreder. Bunlara aldanmamak lâzım. Kötülük ve ahlâksızlık bunların fıtratında vardır.

XIV. bentte şu hususlardan bahsedilmektedir. Güzellerden uzak durmak gerekir. Kişi ne çekerse kendi yaptığını çeker. Âşıkların aklını başından alarak kendilerine bağladıkları için oğlanlardan uzak durulmalıdır. Sözlerinde doğruluk yoktur, işleri güçleri hep yalandır. Bu olumsuz hâlleri ile annelerini ve babalarını üzmektedirler. Bunlar kötü soyludurlar ve asla bunlardan hayır gelmez. Zâtî, Keştî ve Kandî gibi şairler bunların ahlâksızlıklarını yazmışlardır.

\section{Pend-nāme-i Askerī}

\section{Fe' ilātün Mefā` ilün $\mathrm{Fe}^{`}$ ilün}

$\mathrm{I}^{4}$

1 Hūūb-rūlarla ittihāe itme

Meylüñi anlara ziyād itme

2 Kuluñam diyü her çepel-ḥizüñ̃

Dāim emrine inḳıyād itme

3 Ger melek-rū olursa og̉lanı

Severin diyü șaḳın ad itme

4 Furṣat el virse sür șafālarını

Yanuña almaġı murād itme ${ }^{5}$

5 Vuṣlat ümmìidin eyleyüp her ān

Nefs-i şūma uyup fesād itme

6 Ġam-ı hicrān ḳafāda ḥāżırdur

Göñlüñi vașl-1 berle şād itme

$7 \quad$ Kaḥbe vü hīz ile geçer ömri

Șayma șaḳın hịisāba ${ }^{6}$ bād itme

8 Terbiye tașṣı eylemez ḥize

Ehl-i dil sözlerin kesād itme

$9 \quad$ Pend $^{7}$ bed-aṣla fāyide itmez

\footnotetext{
${ }^{4} \mathrm{M} 84 \mathrm{~b}, \mathrm{~T} 3 \mathrm{~b}$.

5 "itme" M'de mükerrer yazılmıştır.

6 “ḥisāba” T’de “ḥisāb” şeklindedir.
} 
Hergiz og̉lana i' timād itme

$10 \mathrm{Her}^{8}$ ne gelse saña gelir andan

Benüm ebedī diyü yād itme ${ }^{9}$

11 Ey göñül pend işit ' inād itme

Kaḥbe vü hīze i` timād itme

$$
\mathrm{II}^{10}
$$

1 Hüsn ile olsa Yūsuf-1 sān̄i

Alma șaḳın yanuña og̉lanı ${ }^{11}$

2 Baştan ayag̉a sīme garḳ itseñ

Saña yār ola șanmağıl anı

3 Sana iżhār idüp ${ }^{12}$ mahabbet-i tām

Kul ider gayrılarla pinhānı

4 Gelse bir kişi akçce gösterse

Seni ḳor aña meyl ider anı

5 Baña n'itdüñ diyü ‘itāb eyler

Eyleseñ dürlü dürlü iḥsānı

$6 \quad \mathrm{Va}^{\mathrm{c}}$ desine hazer ḳıl ald

Bunlaruñ olmaz ahd ü peymānı

7 Hīle fenninde her biri māhir

Mekrile aldır ehl-i c irfānı

8 Belki bunlardan ${ }^{13}$ ögrenür İblīs

Şimdi telbīs birle yalanı

9 Didiler hīzden vefā gelmez gürūh-1 insānı

10 Yüzlerin görmemek sa āa àdetdür

Hele ben şöyle itdüm iz` ānı

11 Ey göñül pend işit ' inād itme

Kaḥbe vü hīze i` timād itme

\section{$\mathrm{III}^{14}$}

1 Mihrüñi eyleseñ eger iżhār

Yanlarında olursun ${ }^{15}$ itden ḩॅ̄âr

\footnotetext{
7 "pend" M'de "say" şeklindedir.

8 T'de "Her ne gelse gelür sana senden" şeklindedir.

9 T'de "yād itdü diyü ād itme" şeklindedir.

${ }^{10} \mathrm{M} 84 \mathrm{~b}, \mathrm{~T} 3 \mathrm{~b}$.

11 T'de "alma yanuña șaḳın og̉lanı” şeklindedir.

12 “idüp" T'de "ider" şeklindedir.

13 "bunlardan" T'de "bunlar" şeklindedir.

${ }^{14} \mathrm{M} 85 \mathrm{a}, \mathrm{T} 4 \mathrm{a}$.
}

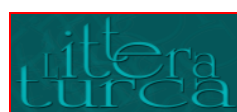


2 Yār żann eyleyüp göñül virsen

Üstüñe ol senün olur bir bār ${ }^{16}$

3 Sözüne şol ḳadar ' inād eyler

Kendüsinden ider seni ${ }^{17}$ bī-zār

4 Șaḳın aldanma kim hilāf eyler ${ }^{18}$

Vac de-i vaṣlın eylese iḳrār

5 ' Āşı̣ u șādıḳ olana bunlar

Ayda bir kerre gösterür dīiār ${ }^{19}$

6 Şāh-rāh-1 maḥabbet içre bular ${ }^{20}$

Oldı ferzīn mis̄āl-i kec-reftār

7 Sìm-berler olur zere mā’ il

Getür ortaya sen dahı neñ var

8 Ger ġıdāsın hemīşe ḳand itseñ

Neñ yedüm diyü cüst ider inkār

9 Az olur bunlar içre ehl-i ḩayā

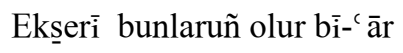

10 Ben Hudā-y-1la böyle ${ }^{21}$ ' ahd itdüm

Bunlara mā'il olmayam Cebbār

11 Ey göñül pend işit c inād itme

Kaḥbe vü hīize i' timād itme

\section{$\mathrm{IV}^{22}$}

1 Kendüsin bir güzel șanur ${ }^{23}$ mümtāz

Saña ḥadden ziyāde eyler nāz

2 Mihrüñi gördi çün ziyāde senüñ

Cevrini çog ider vefāsını az

3 Meskenet birle sen niyāz itseñ

Saña ādem dimez ider ig̀māz

4 Seni ney gibi eyledüp ${ }^{24}$ nālān

Olur ehl-i hevā ile dem-sāz

$5 \quad$ Nerede isteseñ şikār olunur ${ }^{25}$

15 “olursun" T'de "olur" şeklindedir.

${ }^{16}$ M'de misra eksik.

17 “ider seni" T'de "seni ider" şeklindedir.

18 "eyler" T'de "ider" şeklindedir.

19 T'de bu mısraın yerine "Oldı ferzīn mis̄āl-i kec-reftār" mısra1 vardır.

20 T'de bu misra yoktur.

21 "böyle" T'de "şöyle" şeklindedir.

${ }^{22}$ M85b, T4a.

23 “șanur" T'de "șanup" şeklindedir.

24 “eyledüp” M'de “eyleyüp” şeklindedir.

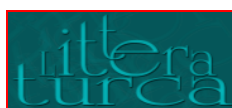


Günde biñ gūşede ider pervāz

6 ' Ār nāmus terk idüp ${ }^{26}$ nā-çār

İlden ' ārlanmayup olur cān-bāz

7 Vaṣlına țālib iken her mug̉lem ${ }^{27}$

Geçinür ${ }^{28}$ kendi muġlem ü zen-bāz

8 Saña şāhinlenür şikār olmaz

Ṣayd ider bir gögercine ḳuş-bāz

9 Cīfeye zāg̣lar olur ${ }^{29}$ țâlib

Lāşeye meyl ider mi hiç şeh-bāz

10 Gūş ḳıl var ise eger ' aḳluñ

Levḥ-i dilde sözümi ${ }^{30}$ hille-bāz

11 Ey göñül pend işid ' inād itme

Kaḥbe vü hīze i` timād itme

$$
\mathrm{V}^{31}
$$

1 Hūublar oldılar iñen nā-pāk

Meyl ider mi bulara ' āşı̣̂-1 pāk

2 Perde-i 'ișmetini her bir dūn

Dest-i ālāyişile eyler çāk

3 Gece gündüz sürer șafālarını

Ehrimenlerle bir bölük itrāk

4 Söyleşür müdde ${ }^{`}$ īler ile varup

Şād iken ḩāṭ̂ruñ ider ġam-nāk

5 Bunlar ehl-i hevāya meyl eyler

Fi'l-meșel ${ }^{32}$ yollarında olsañ hāak

6 İtme diyü nașị̂hat itseñ eger

Kaṣd ider tā ki seni ide helāk

7 Kimse bilmez bunı ne hikmetdür

Saña sem gösterür eyler ${ }^{33}$ tiryāk

8 Yoḳ durur gerçi hiç birinde ${ }^{34}$ vefā

Katı hercāyīdür velī dellāk

25 “olunur" T'de "olur" şeklindedir.

26 T'de “"ār u nāmusı terk ider” şeklindedir.

27 T'de "vaslınuñ țalibi iken muğlem" şeklindedir.

28 "geçinür" M'de "geçmez" şeklindedir.

29 “olur" T'de "olup" şeklindedir.

30 T'de "sözümü" kelimesi başta yazılmıştır.

31 M85b, T4b.

32 T'de "fi'l-mesel ger yolında" şeklindedir.

33 "eyler" T'de "aña" şeklindedir.

34 T'de "hiç birinde gerçi vefâ" şeklindedir.




9 Merḥamet ḳılmaz ' āşıḳa bunlar

Devr idelden berü tọuuz eflāk

10 Sözümi itme redd ḳabūl eyle

Varise sende zerrece idrāk

11 Ey göñull pend işid ' inād itme

Kaḥ̣be vü ḥize ic timād itme

$$
\mathrm{VI}^{35}
$$

1 Ṭoldı hercāyilerle çün āfāk

Nice rencīde olmasun ' uşşāḳ

2 Hazer it virme sāde-rūya gönüul

Fi'l-mesel ger olursa hüsnile tạạ

3 ' Āşı̣ u șādıḳa bular baḳmaz

Yanlarında mu'azzez ehl-i nifāk

4 Gelse yanına bir ġulām-pāre

Seni ḳor aña geçinür müştāḳ

5 Gāh şīveyle șâ̄ idin șigayup

'Arż ider ġāhī aña sīmīn-sāḳ

6 İtme diseñ ezā niçün fí'l-hāal

Nisbetüñe varur odasına çāk

7 Pāk-dāmen șunar saña kendin

Līk tenhāda dökdürür şāḳ şāḳ

$8 \quad$ Olsa bir meclis içre ger ikisi

Çeker elbette birbirine bıçak

9 Kurtılur faḳr ile felāketden

Kim ki bunlardan olur ise irak

10 Geç bularuñla 'ayş u 'işretden

Nefse uyup Hudāya olmağıl ‘ àk

11 Ey gönül pend işid ' inād itme

Kaḥbe vü hīze i` timād itme

$$
\mathrm{VII}^{36}
$$

1 Sāde-rūlar olursa nesl-i melek

Çekme żāyi` olur anuñ'çün emek

$2 \quad$ Șan ${ }^{`}$ at u pişe bunlara şeb u rūz

Aldayup 'āşı̣̂ın hemişse yemek

$3 \quad$ Nān degül belki cān yedirseñ ${ }^{37}$ eger $^{38}$

${ }^{35}$ M86a, T'de yoktur.

${ }^{36} \mathrm{M} 86 \mathrm{~b}, \mathrm{~T} 6 \mathrm{~b}$.




Gözlemez hiç birisi ḥaḳk-ı nemek

4 Şol ḳadar hüsne garrādur bunlar

Ki dimezler felege şimdi kelek

5 Şimdi bunlardan ögrenür şikeste ${ }^{39}$

Bī-vefālık yolını belki ${ }^{40}$ felek

6 Baña șor tecrīm çog olmışdur

Kalbi fark eylemez meger ki mehek

$7 \quad$ Kanda giderler ise ḳaçsa mis̄āl

Șalınur yanlarınca bile me ek

$8 \quad$ Terk iderler ${ }^{41}$ yolına mā-meleki

Girse bir tek eline ger beli pek

9 Sen gerek degerüñ ḳabūl eyle

Hele baña düşen budur ki dimek

10 Ey gönül pend işit ' inād itme

Kaḥbe vü hīize i` timād itme

\section{$\mathrm{VIII}^{42}$}

$1 \quad$ Ṣıdḳla sevse ger bir ehl-i kemāl

Aña mekr ü füsūnla ider āl

2 Yüz-be-yüz ' ārı terk idüp dirler ${ }^{43}$

Ma' rifet n'eyleriz gerek bize māl

3 Sen anı iller üzre dutar iken

Ol senüñ ' arżuñı ider pā-māll $1^{44}$

4 Saña gelse yüzi gözi gülmez

Olur ag̉yārını göricek ḩoş-ḥāl

5 Oțasından erezlık çı়̣maz

Saña gelmek yanında emr-i muhāl

6 Șakınursın sen anı cāndan pek

Gördi ḳuçmaz sen eyleyüp ihmāl

7 Saña geldügi vaḳtde 'ārifseñ

Ṣal koluñ boynına vü būsesin al

$8 \quad$ Hīzdür yüz bulur hicābi $1^{45}$ gider

37 “yedirseñ” T'de "verirseñ” şeklindedir.

38 “eger" T' de "inan" şeklindedir.

39 "şikeste" T'de "tahkik" șeklindedir.

40 "belki” T'de "şimdi” şeklindedir.

41 “iderler" T'de "idersen" sseklindedir.

${ }^{42}$ M86b, T7a.

43 “dirler" T'de "didiler" şeklindedir.

${ }^{44}$ Bu mısra1 "Olur ag̉yārını göricek hoş-ḩāl” T'de şeklindedir.

45 "ḥicābı" M'de "ḥicāb" şeklindedir.

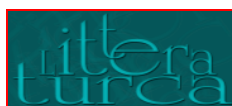


Gözin açdırma hiidmet it fi'l-ḥāl

9 Șūretā gerçi kim yalıñ yüzlüler ${ }^{46}$

Ma'nāda her birisi bed-efāl

10 Ey gönül pend işit ' inād itme

Kaḥbe vü hīize i` timād itme

\section{IX}

1 Başına üşdi bir nice evbāş

Adını ḳoyuben senüñ ' ayyāş

2 Rūz u şeb anlar gele 'işretde

Zikr ü fikrüñ hemīşe gözile ḳaş

3 Nuțuña her biri olup teslimm

Her ne söz söyleseñ ider sābāş

4 Mey ü maḥbūb olunca ḩāneñde

Her biri saña ${ }^{47}$ cān ile sırdaş

5 Kalmadı çün yañuñda sīm ü zerüñ

Gördiler seni müflis ü ḳallaş

6 Cümle meclisde 'aybuñ söyler

Kanı ol saña yār olan yoldaş

7 Şöyle yüz dönderür ḳaçar senden

Komadı șanki hiçbir yere baş

8 Çevirüp her birisi senden yüz

Seni her yerde ġybet eyler fāş

9 Kahbe vü hīize aḳçe pul yitmez

Sīm ü zer olsa yeryüzündeki țaş

10 Başuma geldi cümle ${ }^{48}$ ben gördüm

Söz güherdür șaḳın șıma ḳardaş

11 Ey gönüul pend işit ' inād itme

Kaḥbe vü hīize i` timād itme

$$
\mathrm{X}^{49}
$$

1 Ḩāne-i ḳalbüñi idince ḩarāb

Virür aġrāzla sözüñe cevāb

2 Ālile ald1 ${ }^{50}$ göñlüñi senden

Cānuña başlar eylemege 'az̄āb

46 Bu misra "șūretā hūb yüzlü gerçi” T'de şeklindedir.

47 "saña cān ile" T'de "cānla saña" şeklindedir.

48 “cümle ben gördüm” T'de "ben cümle gördüm” şeklindedir.

${ }^{49}$ M87b, T4b.

${ }^{50} \mathrm{~T}$ 'de “alla aldı çün gönül senden” şeklindedir.

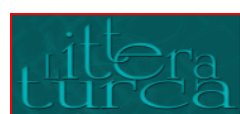


3 Geh ḳaḳır geh söger eyler nāz

Söylemek ḳaṣd iderseñ eyler ' iḳāb

$4 \quad$ Sen hevā āteşiyle yanmaḳda

Meyl ider her denīye ol çün āb

5 Rūz u şeb cem` olup erez ile

Nūş ider gūşe gūşe cām-1 şarāb

6 Ṣaçınuñ șağışııdan artuḳdur

Eylesen $^{51}$ s.k.l.d.g.ñi ḥisāb

$7 \quad$ Bu ḳadar 'ayb ile ol mef ${ }^{\natural} \bar{u}^{5}{ }^{52}$

Fā' iline geçinür ehl-i hịcāb

8 Cümle ālāyiş ile ālūde

Pāk-dāmānı bunlaruñ kem-yāb

9 Pāk-bāz ol hümā-şikār eyle

İtme murdāra meyl olma kelāb

10 Ey göñül pend işid ' inād itme

Kāḥbe vü hīze i` timād itme

$$
\mathrm{XI}^{53}
$$

1 Çekmeyem diriseñ eger żllet

Gördügüñ hūba eyleme ragibet

2 Ki getürmez ḥazer ḳıl og̉lana

Ḳılma ḥadden ziyāde sen hürrmet

3 Müşteri çog̀ ola diyü her gün

Kend'özin zeyn ider șatar şöhret

4 Hुāneñe gelmek eylerse iḳrār

$\mathrm{Va}^{\text {c }}$ desine bulur niçe ' illet

5 Bir iki gün senüñle cem` olsa

Getürür başuña senüñ nekbet

6 Naḳd-i cānı yolunda hyarc itseñ

' Āşı̣̂a eylemez velī şefḳāt

7 Raḥm idüp her erezile müşfik

Buldugi mugilime ider 'izzet

8 Pāk-dāmāna yoḳ sözüm aṣla

Ḥīz-i nā-pāke günde biñ la' net

9 Senin akçceñ puluñ yiyüp her dem

Vaṣlını gayrıya ider himmet

\footnotetext{
${ }^{51} \mathrm{M}$ ve T'de "ger" kelimesi var.

52 "mef' üli” T'de "mef ūl”" şeklindedir.

${ }^{53}$ M87b, T'de yoktur.
} 
10 Ey gönül pend işit ' inād itme

Kạ̣be vü hịize i` timād itme

\section{$\mathrm{XII}^{54}$}

1 Hुūblar olmaz 'āḳıbet-endīş

Rūz u şeb 'aşḳına çekmegil teşviş

2 Nūş ider şehd-i la' lini her dūn

Zehr-i ḳahr ile saña șunar nīş

3 Kendüyi on iki yaşında șanur

Pest ü penç ${ }^{55}$ idüben getürmiş rī̧s

4 Dadın almış s.k.şmegin bunlar

Didiler birbirine budur iş

$5 \quad$ Cem $^{`}$ olup rūz u şeb āvānile

Göz göre evde iderler ${ }^{56}$ s.k.ş

6 Tīrşesine virürken āşı cān

Geçer el șofrasına ḍarb-ı çiriş

7 'Arż iderler bu halka 'ārıż u ḳad

Lìk ḍarb-1 t.ş.kla g.tleri şiş

8 Țaşradır yetmiş iki milletden

Bunlar İblīs iledir hem kīş

9 Şerḥ olunmaz ḳabāḥati bularuñ

Sözüñi eyle ${ }^{57}$ muḥtașar derviş

10 Ey gönül pend işit ' inād itme

Kaḥbe vü hīze i` timād itme

\section{$\mathrm{XIII}^{58}$}

1 Hūblar șalup elden inșāfı

' Āşı̣ka oldılar ḳatı cāfī

2 ' Āşı̣̦a ḳahr idüp cefālar ider

Bizligin ḩās u 'āma elțāfic ${ }^{59}$

3 Meyl ḳılmaz bular ne hikmetdür

Șu gibi ḳalbi olana șāfí

4 Saña gelmege ' $\bar{a} d d$ ider ilden

Seyr ider her denīyle eṭrāfi

5 Aldanup va' desine bun düşme

\footnotetext{
${ }^{54}$ M88a, T7a.

${ }^{55} \mathrm{~T}$ 'de "pest ü pençe idüp" şeklindedir.

56 T'de "Körligüñe iderler evde" şeklindedir.

57 "sözüñi eyle" T'de "sözi ḳıl eyle" şeklindedir.

${ }^{58} \mathrm{M} 88 \mathrm{a}, \mathrm{T} 6 \mathrm{~b}$.

59 “elțāfi” T’de “ị̣sānı” şeklindedir.
} 
Çog olur bunlaruñ șaḳın lāfı

$6 \quad$ Hak bilür ḳahbeden çog artuḳdur

Bī-vefālıḳda şehrüñ eclāfı

7 Heves ider s.k.şmege bunlar

Ebesi $^{60}$ kesdügi gibi nāfı

8 Görmedük ${ }^{61}$ didiler vefādan eser

Seyr idenler bu cümle eknāfí ${ }^{62}$

9 Bulmadum hiç birinde ben de vefă ${ }^{63}$

Aradum bir bir cümle eșnāfi ${ }^{64}$

10 Ne diyem kim işitmemiş olasın

Dānişüñ varsa bu ḳadar kāfi

11 Ey göñül pend işit ' inād itme

Kaḥbe vü hīze i` timād itme

$\mathrm{XIV}^{65}$

1 'Askerīnüñ budur saña pendi

Hūub-rūlarla itme peyvendi

2 İlden işütdügi degül yalıñuz

Başına geldi çekdi hep kendi

3 Ḥizlerden ḥazer gerek muḥkem

' $\bar{A} s ̧ 1 k$ çok ${ }^{66}$ geçer bulur bendi

4 Düşürür vādī-i cünūna bular

' $\bar{A} k l ı n$ alup niçe ḩıred-mendi

5 Kavlinüñ yoḳ ḳarārı va de hilāf

Hep yalandur inanma sevgendi

6 İtmiş atası anasın bī-zār ${ }^{67}$

Her birine bir zamāna ferzendi

$7 \quad$ Yanlarında ' azīz olur bularuñ ${ }^{68}$

Şehrüñ evbaşı rind ü ...

8 Bed-āṣıldan vefā gelür șanma ${ }^{69}$

Didi maḩmūre şāha meymendi

\footnotetext{
60 “ebesi” T'de "anası" şeklindedir.

61 "Görmedük" T'de "Görmedüm” şeklindedir.

62 "eknafi” T'de "esnafi” șeklindedir.

${ }^{63} \mathrm{Bu}$ beyit T'nin 5 . beyti olmuştur.

64 “esnafi" T'de "eknafi” șeklindedir.

${ }^{65} \mathrm{M} 88 \mathrm{~b}, \mathrm{~T} 7 \mathrm{~b}$.

66 “çok" T'de "çün” şeklindedir.

${ }^{67}$ M'de "Eylemiş atasın anasın āzār" şeklindedir.

${ }^{68} \mathrm{Bu}$ beyit M'de yoktur.

${ }^{69} \mathrm{Bu}$ beyit M'de yoktur.
}

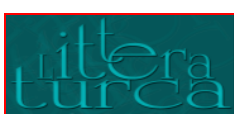


9 Niçe niçe ḳabāḥatin bularuñ ${ }^{70}$

Yazdı Zāâi vü Keştī vü Kandī

10 Gelecekler dahı neler diyeler ${ }^{71}$

Bunlaruñ haḳḳına neler dendi

11 Ey gönül pend işit ' inād itme ${ }^{72}$

Kaḥbe vü ḥize ic timād itme

\section{SONUÇ}

İnsanları iyiye, doğruya, güzele sevk eden her şey, pendname olarak adlandırılabilir. Askerî́nin de pendnamesinde halkı güzel ve doğru olana yönlendirme çabasında olduğu görülmektedir. Eşcinsellik konusunu ele alan şair, eşcinselliğin doğru olmadığı, bu yolda gidenlerin yanlış yaptığı ve bu yoldan dönülmesi gerektiği gibi hususlar üzerinde durmuştur. Sözünü etkili kılmak için çarpıcı örnekler vermekten kaçınmamış, yer yer müstehcenliğe varan sözler sarf etmiştir. Eserin geneline batığımızda müstehcenliğin çokça tercih edilmediği görülmektedir.

Eser, Osmanlı döneminde her ne kadar görmezden gelinmiş olsa da eşcinselliğin var olduğunu ve edebî metinlere yansıdığını; fakat bu eğilimlerin toplumun hoş göreceği bir seviyeye çıkmadığını ve de eleştirildiğini göstermesi bakımından önemlidir.

\section{Kaynakça}

EKiNCi, Ramazan, (2012). “16. Asırda Yazılmış Mensur Bir Nasihat-name Abdulkerim Bin Mehmed'in Nesâyihü’l-

Ebrar'ı". Turkish Studies - International Periodical For The Languages, Literature and History of Turkish or Turkic 7 (2): 423-441.

GÜVEN, A. Zeki (2009).“Edirneli Nazmi'nin Pendnamesinde Eğitim ve Ahlak Anlayışı”. International Periodical Forthe Languages, Literature and History of Turkish or Turkic 4 (5) 2009: 182-197.

KAPLAN, Mahmut (2008). Hayriyye-i Nabi. Ankara: AKM Yay.

KAPLAN, Yunus (2014). “Askerî, Mehmed”.

http://www.turkedebiyatiisimlersozlugu.com/index.php?sayfa=detay\&detay=1478 [erişim tarihi: 19.04.2016].

KILIÇ, Filiz (2010). Âşık Çelebi, Meşâ'irü'ş-Şu'arâ-inceleme-Metin. C.2.İstanbul: İstanbul Araştırmaları Enstitüsü Yay.

KUTLU, Mustafa (1990). “Pend-nameler”.Türk Dili ve Edebiyatı Ansiklopedisi. C.7.i̇stanbul: Dergâh Yay.,241-242. KUTLUK, Ibrahim (1989). Kınalı-zade Hasan Çelebi Tezkiretü'ş-Şuarâ. C. II. Ankara: AKM Yay.

PALA, İskender (2002). "Nasihatname”. İslâm Ansiklopedisi. C. 32. İstanbul: TDV Yay. İstanbul: 409-410.

\footnotetext{
${ }^{70} \mathrm{Bu}$ beyit M'de yoktur.

${ }^{71} \mathrm{Bu}$ beyit M'de yoktur.

${ }^{72} \mathrm{Bu}$ beyit M'de yoktur.
}

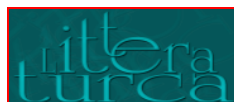

